\title{
SISTEM INFORMASI GEOGRAFIS PENCARIAN LOKASI BANK DAN ATM DI KOTA TERNATE BERBASIS WEB
}

\author{
Ahmad Junaidy Mustafa ${ }^{l}$, Abdul Mubarak ${ }^{2}$, Rosihan $^{3}$ \\ Program Studi Teknik Informatika, Fakultas Teknik, Universitas Khairun \\ Jl. Jati Metro, Kota Ternate Selatan \\ E-mail : djunaidymustafa@gmail.com ${ }^{1}$, abdulmubarak029@gmail.com², \\ rosihan.unkhair@outlook.com ${ }^{3}$
}

\begin{abstract}
Abstact -- Immigrants and communities in the city of Ternate are difficult to find location information from banks and automated teller machines (atm) quickly and easily. This situation occurs because the government of Ternate City has not created a system that provides information from the location of banks and automated teller machines(atm) to help immigrants and the communities in Ternate City. Geographic information system (GIS) is better in providing information because GIS provides an overview of the location of banks and atm in the form of spatial data and non spatial data are presented in digital form that helps immigrants and the communities in finding the location of banks and automated teller machines(atm) exist in Ternate City. This study aims to design and build geographic information systems search location of banks and atm which in the design using UML to describe the activities of system actors and ERD in relating the tables. While in making the system using PHP programming language, for the view of the system using bootstrap and CSS, map making used QGIS and Leafleat, and Postgresql as database. To develop the system used prototype method. On the test results of data tested starting from the correct data or wrong data, can run well and in accordance with the design of geographic information systems search location of banks and atm.
\end{abstract}

Keyword : GIS Location of Bank \& ATM, Prototype, QSIG, PHP, Postgresql

Abstrak -- Pendatang dan masyarakat yang ada di Kota Ternate kesulitan dalam mencari informasi lokasi dari bank dan atm secara cepat dan mudah. Keadaan ini terjadi karena pemerintah Kota Ternate belum membuat sebuah sistem yang memberikan informasi dari lokasi bank dan atm unutuk membantu pendatang dan masyarakat yang ada di Kota ternate. Sistem informasi geografis (SIG) lebih baik dalam memberikan informasi karena SIG memberikan gambaran dari lokasi bank dan atm berupa data spasial dan data non spasial yang di sajikan dalam bentuk digital yang membantu pendatang dan masyarakat dalam mencari lokasi bank dan atm ada di Kota Ternate. Penelitian ini bertujuan untuk merancang dan membangun sistem informasi geografis pencarian lokasi bank dan atm. Dimana dalam perancangan menggunakan UML unutk mendiskripsikan kegiatan aktor sistem dan ERD dalam merelasi tabel-tabel. Sedangkan dalam pembuatan sistem menggunakan bahasa pemograman PHP, untuk tampilan dari sistem menggunakan bootstrap dan CSS, pembuatan peta digunakan QGIS dan Leafleat, dan Postgresql sebagai basis data. Untuk mengembangan sistem digunakan metode prototype. Pada hasil pengujian data yang diuji mulai dari data yang benar maupun data yang salah, dapat berjalan dengan baik dan sesuai dengan hasil perancangan sistem informasi geografis pencarian lokasi bank dan atm.

Kata Kunci : SIG lokasi Bank \& ATM, Prototype, QGIS, PHP dan Postgresql

\section{PENDAHULUAN}

\subsection{Latar Belakang}

Kota Ternate merupakan ibu kota dari Pemerintah Daerah yang berada di Provinsi Maluku Utara, Ternate pertama menjadi Kota otonom sejak 4 Agustus 2010, dan pernah menjadi Ibu Kota sementara sebelum Ibu kota Sofifi di Provinsi Maluku Utara. Kota Ternate terletak di pulau Ternate dengan luas wilayah $111,39 \mathrm{~km}^{2}$ dan jumlah jiwa 207.789 (Data BPS-Kota Ternate dalam angka 2015).

Masyarakat pada umumnya dan pendatang pada khususnya kesulitan untuk mencari lokasi Bank dan ATM dalam keperluan sehari-hari. Masyarakat pendatang merasa kurang akan informasi tentang letak kantor cabang, kantor cabang pembantu beserta lokasi ATM yang dapat diperoleh secara cepat dan mudah.
Keadaan ini terjadi karena belum ada sistem yang secara otomatis memberi informasi lokasi dari kantor cabang Bank, kantor cabang pembantu beserta lokasi ATM.

Penyajian data informasi lebih baik bila menggunakan Sistem Informasi Geografis (SIG) karena SIG memberikan informasi data Spasial dan data Non-Spasial yang memberikan data dari lokasi bank, cabang pembantu dan ATM. Dengan adanya SIG masyarakat dapat terbantu dalam keperlulan yang dibutuhkan. Salah satu informasi yang dibutuhan oleh masyarakat adalah letak bank, cabang pembantu dan ATM yang dengan menyajikan data lokasi cabang bank, cabang pembantu dan ATM, diharapkan dapat membantu masyarakat dalam mencari lokasi tersebut di Kota Ternate. 
Berdasarkan pemikiran tersebut penulis mencoba untuk membuat "SISTEM INFORMASI GEOGRAFIS PENCARIAN LOKASI BANK DAN ATM DI KOTA TERNATE BERBASIS WEB".

\subsection{Tujuan Penelitian}

Adapun tujuan dari penelitian yang dilakukan yaitu:

1. Merancang Sistem Informasi Geografis Pencarian Lokasi Bank dan ATM di Kota Ternate Berbasis web

2. Membuat Sistem Informasi Geografis Pencarian Lokasi Bank dan ATM di Kota Ternate Menggunakan Quantum GIS 2.16 dan Bahasa Pemograman PHP.

\subsection{Manfaat Penelitian}

Manfaat yang diharapkan dari penelitian ini adalah:

1. Menambah wawasan penulis dalam membuat Sistem Informasi Geografis yang dipadukan dengan Web.

2. Membantu masyarakat dalam mencari informasi dari lokasi bank, cabang pembantu, dan ATM.

3. Sebagai tempat promosi bagi pemilik Bank yang ada di Kota Ternate

\section{TINJAUAN PUSTAKA}

A. Bank

Menurut Undang- Undang No. 10 Tahun 1998, bank adalah badan usaha yang menghimpun dana dari masyarakat dalam bentuk simpanan dan menyalurkannya kepada masyarakat dalam bentuk kredit dan/atau bentuk- bentuk lainnya dalam rangka meningkatkan taraf hidup rakyat banyak.

1. Pengertian Bank Umum adalah bank yang melaksanakan kegiatan usahanya secara konvensional dan atau berdasarkan prisip syariah yang dalam kegiatannya memberikan jasa lalu lintas pembayaran.

2. Bank Perkredit an Rakyat adalah bank yang melaksanakan kegiatan usaha secara konvensional atau berdasarkan prinsip syariah yang dalam kegiatannya tidak memberikan jasa lalu lintas pembayaran.

\section{B. ATM}

ATM adalah sebuah alat elektronik yang mengijinkan nasabah perbankan untuk mengambil uang dan mengecek rekening tabungan mereka tanpa perlu dilayani oleh seorang "Teller" di Bank. Banyak ATM juga berfungsi untuk penyetoran uang atau cek, transfer uang dan transaksi perbankan lainnya. Pada mulanya mesin pintar ini ditemukan oleh Don Wetzel, Vice President of Product Planning pada perusahaan Docutel. Konsep ATM pertama kali lahir pada tahun 1968, lalu prototipenya muncul setahun kemudian, dan akhirnya Ducotel mendaftarkannya pada Kantor paten pada tahun 1973 [1].

\section{Quantum GIS}

QGIS adalah perangkat Sistem Informasi Geografis (SIG) Open Source yang user friendly dengan lisensi di bawah GNU General Public License. QGIS merupakan proyek tidak resmi dari Open Source Geospatial Foundation (OSGeo). QGIS dapat dijalankan pada Linux, Unix, Mac OSX, Windows dan Android, serta mendukung banyak format dan fungsionalitas data vektor, raster, dan basisdata. (www.qgis.org)

\section{Kota Ternate}

Kota Ternate adalah sebuah kota yang berada dibawah kaki gunung api Gamalama pada sebuah Pulau Ternate di Provinsi Maluku Utara, Indonesia. Kota Ternate merupakan kota kepulauan yang memiliki luas wilayah $547,736 \mathrm{~km}^{2}$, dengan 8 pulau yaitu Pulau Ternate, Pulau Hiri, Pulau Moti, Pulau Mayau, dan Pulau Tifure merupakan lima pulau yang berpenduduk, sedangkan terdapat tiga pulau lain seperti Pulau Maka, Pulau Mano dan Pulau Gurida merupakan pulau berukuran kecil yang tidak berpenghuni.

Ternate menjadi satu kota otonom sejak 4 Agustus 2010 dan pernah menjadi ibu kota sementara Provinsi Maluku Utara sampai Sofifi yang menjadi ibu kotanya di Pulau Halmahera siap secara infrastruktur. Walaupun kota Ternate ini tergolong kota kecil yang tidak terlalu luas, sebagai suatu kota mempunyai beberapa latar belakan masyarakat yang berbeda. Perbedaan latar belakan masyarakat tersebut telah menyebabkan muncul sosial budaya masyarakat yang berbeda pula [2].

\section{E. PostgreSQL}

PostgreSQL adalah sebuah objek relational databases server (database management system) yang bebas. Menawarkan alternative untuk sistem database yang lain, dan mirip dengan projek Open Source yang lain seperti Apache, Linux, dan Mediawiki [3].

\section{METODE PENELITIAN}

A. Pengembangan Perangkat Lunak

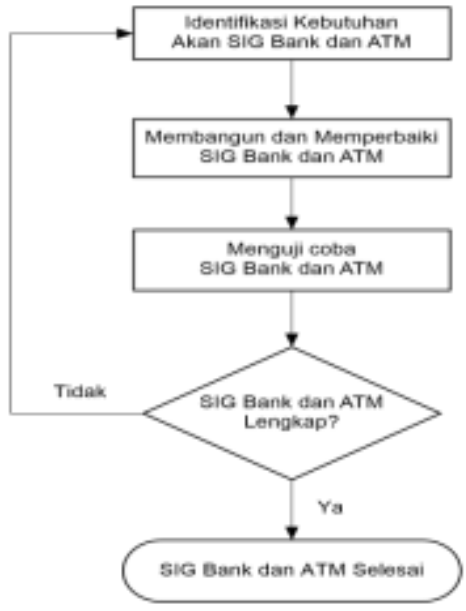

Gambar 1 Pengembangan Perangkat Lunak Menggunakan Prototipe

Deskripsi Pengembangan Sistem:

1. Identifikasi kebutuhan-kebutuhan dalam hal ini kebutuhan dalam SIG Pencarian Lokasi Bank dan ATM. 
2. Setelah mengidentifikasi kebutuhan dari sistem kemudian membangun dan memperbaiki SIG Bank dan ATM menggunakan Bahasa Pemograman PHP dan Leafleat.

3. Setelah tahap membangun SIG selesai lanjut ke tahap pengujian dengan melibatkan admin dan user.

4. Jika dalam tahapan pengujian ditemukan SIG Bank dan ATM belum lengkap maka dilakukan perbaikan pada sistem berdasarkan kebutuhan yang baru.

Apabila SIG Bank dan ATM telah lengkap maka selesai. Apabila tidak lengkap maka kembali mengidentifikasi kebutuhan sistem yang masih kurang.

\section{B. Blok Diagram}

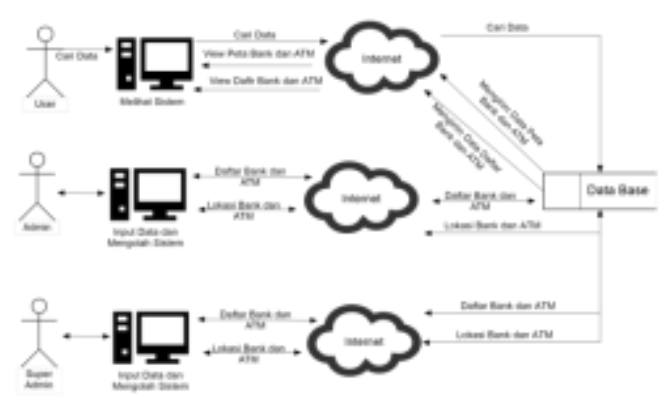

Gambar 2 Blok Diagram SIG Pencarian Lokasi Bank dan ATM

Deskripsi Blok Diagram:

1. User mencari informasi Lokasi Bank dan ATM pada sistem dengan memasukan data yang dibutuhkan, kemudian sistem mencari data Bank dan ATM dalam database melalui jaringan Internet, setelah data dari Bank dan ATM yang dibutuhkan user didapat dari database, maka sistem menampilkan data tersebut kepada user sesuai kebutuhan dari user.

2. Tugas Admin hampir sama dengan super admin tetapi terdapat batasan untuk admin, dimana admin hanya menginput data Bank dan ATM beserta lokasi dan mengolah data bank hanya satu bank untuk tiap-tiap admin .

3. Super Admin menginput data Bank dan ATM beserta Lokasi pada sistem, kemudian sistem memasukan data Bank dan ATM beserta Lokasi pada database melalui jaringan Internet, setelah data berhasil diinput maka sistem menampilkan kembali data yang diinput admin, selain menginput data admin juga mengolah sistem tersebut

C. Use Case Diagram

Use Case adalah deskripsi dari urutan aksi-aksi yang ditampilkan sistem yang menghasilkan suatu hasil yang terukur bagi suatu actor. Use Case disini terdiri dari tiga yaitu Use Case Admin, Use Case User dan Use Case User.

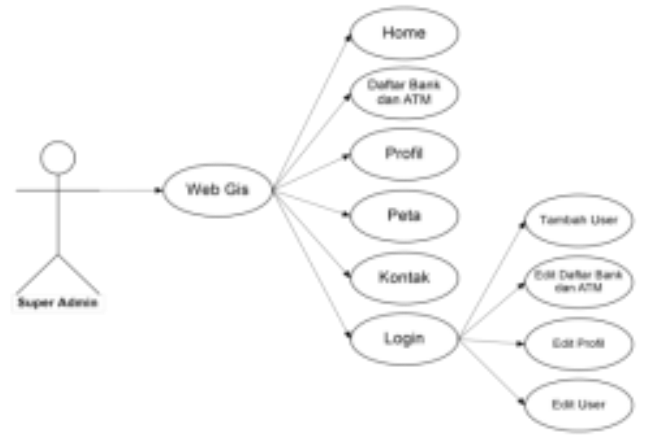

Gambar 3 Use Case Diagram Super Admin

Deskripsi Use Case Admin:

1. Super Admin membuka web gis Pencarian Lokasi bank dan ATM.

2. Setelah membuka web gis terdapat pilihan menu yaitu: Home dimana terdapat halaman awal dari webgis pencarian lokasi bank dan atm, Daftar bank dan ATM terdapat data dari lokasi bank dan ATM yang ada di Kota Ternate, Profil dimana Terdapat profil dari Pemerintah Kota ternate, Lokasi Bank dan ATM dimana terdapat Lokasi Bank dan ATM Kota Ternate dan lokasi dari Bank dan ATM yang ada di Kota ternate, Kontak dimana nanti masyarakat / user dapat menghubungi Admin, dan Login dimana terdapat halaman back end dimana halaman yang hanya bisa dimasuk oleh Admin / Super Admin.

3. Halaman back end hanya bisa dimasuk oleh admin karena dihalaman ini admin menginput dan mengedit Lokasi Bank dan ATM, daftar Bank dan ATM dan isi dari profil.

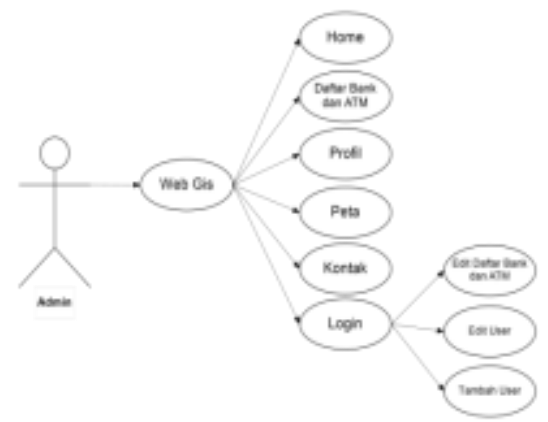

Gambar 4 Use Case Diagram Admin

Deskripsi Use Case User:

1. Admin membuka Web gis Pencarian Lokasi Bank dan ATM.

2. Setelah membuka web gis terdapat pilihan menu yaitu : Home dimana terdapat halaman awal dari webgis pencarian lokasi bank dan atm, Daftar bank dan ATM terdapat data dari lokasi bank dan ATM yang ada di Kota Ternate, Profil dimana Terdapat profil dari Pemerintah Kota ternate, Lokasi Bank dan ATM dimana terdapat Lokasi Bank dan ATM Kota Ternate dan lokasi dari Bank dan ATM yang ada di Kota ternate, Kontak dimana nanti masyarakat / user dapat menghubungi Admin, dan Login dimana terdapat 
halaman back end dimana halaman yang hanya bisa dimasuk oleh Admin / Super admin.

3. Halaman back and hanya bisa di akses oleh admin dan super admin di dalamnya terdapat menu untuk mengolah sistem, ada batasan untuk admin dalam mengolah sistem yaitu admin hanya bisa menginput data bank dan ATM sesuai dengan data dari admin.

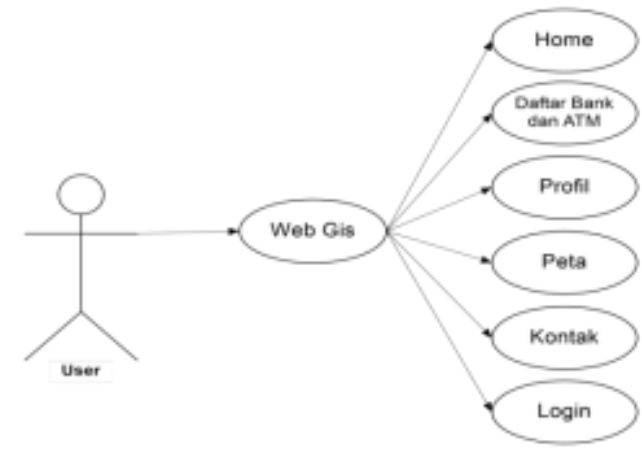

Gambar 5 Use Case Diagram User
1. User membuka web gis Pencarian Lokasi bank dan ATM.

2. Setelah membuka web gis terdapat pilihan menu yaitu: Home dimana terdapat halaman awal dari webgis pencarian lokasi bank dan ATM, Daftar bank dan ATM terdapat data dari lokasi bank dan ATM yang ada di Kota Ternate, Profil dimana Terdapat profil dari Pemerintah Kota ternate, Lokasi Bank dan ATM dimana terdapat Lokasi Bank dan ATM Kota Ternate dan lokasi dari Bank dan ATM yang ada di Kota ternate, Konten dimana nanti masyarakat / user dapat menghubungi Admin, dan Login dimana terdapat halaman back end dimana halaman yang hanya bisa dimasuk oleh Admin / Super Admin.

D. Perancangan Database

Perancangan Database merupakan proses untuk menentukan isi dan pengaturan data yang dibutuhkan untuk mendukung berbagai rancangan sistem. Perancangan database menggunakan ERD (Entity Relationship Diagram).

Deskripsi Use Case User:

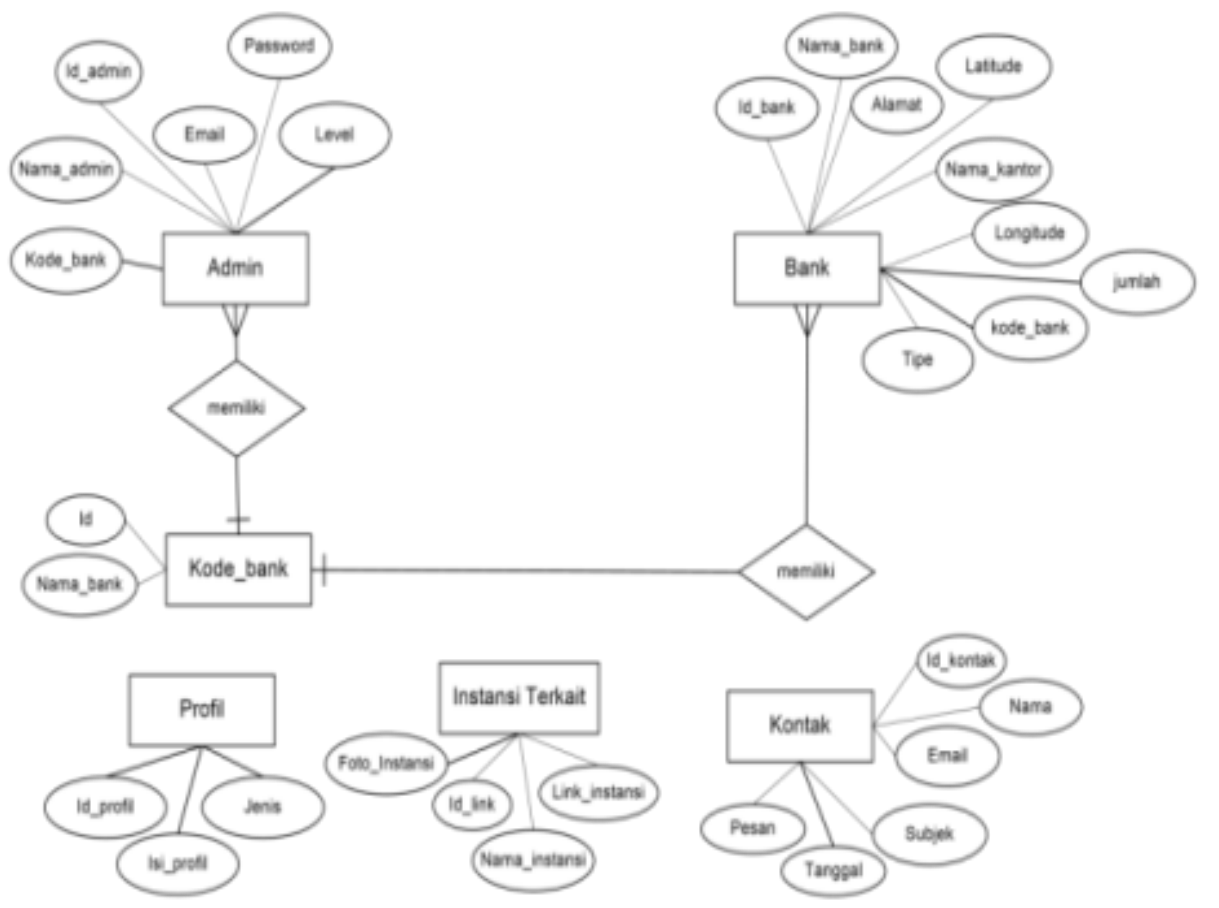

Gambar 6 ERD Sistem Informasi Geografis Pencarian Lokasi Bank dan ATM Di Kota Ternate

Deskripsi Sistem:

1. Admin : \{id_admin, nama_admin, password, email, level, kode_bank\}, Bank \{id_bank, nama_bank, nama_kantor, Alamat, latitude, longitude, kode_bank, jumlah\}, Kode Bank : \{id, kode_bank\}.

2. Terdapat tiga relasi yaitu "relasi menginput" yang menghubungkan entitas admin dan Bank, "relasi memiliki" yang menghubungkan entitas admin dan kode bank, dan "relasi memiliki" yang menghubungkan entitas kode bank dan Bank

\section{IV.HASIL DAN PEMBAHASAN}

A. Rekayasa Dan Pengembangan Sistem

1. Activity Diagram

Activity Diagram menggambarkan berbagai alir aktivasi dalam sistem yang sedang dirancang, bagaimana masing-masing alir berawal, descision yang mungkin terjadi, dan bagaimana mereka berakhir. Activity diagram juga dapat menggambarkan proses paralel yang mungkin terjadi pada beberapa eksekusi 


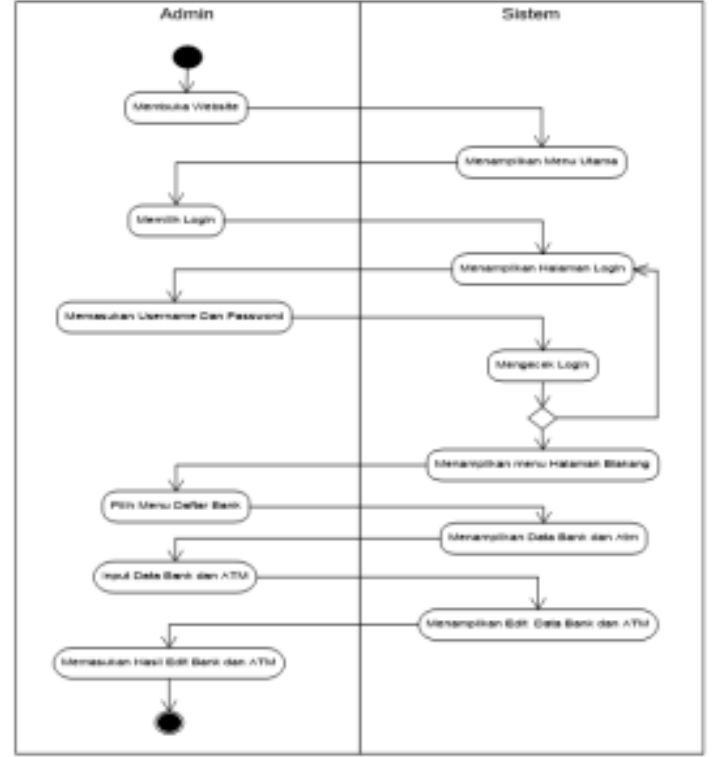

Gambar 7 Diagram Activity "Daftar Bank"

Keterangan:

1. Membuka website terlebih dahulu mengakses halaman login.

2. Setelah tampilan login maka admin mengisi username dan password.

3. Apabila username dan password benar maka akan ditampilkan halaman belakan.

4. Apabila username dan password salah makan akan ditampilkan halaman login.

5. Setelah tampilan halaman belakan maka pilih menu daftar bank.

6. Kemudian akan muncul halaman input daftar bank untuk melakukan penginputan.

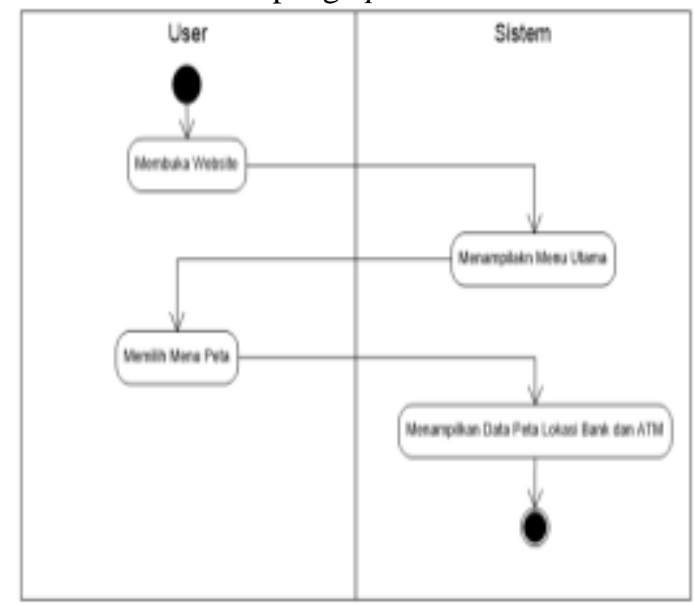

Gambar 8 Diagram Activity "Lokasi Bank dan ATM"

Keterangan:

1. Membuka website dan sistem akan menampilkan halaman depan.

2. Setelah itu pilih menu Lokasi Bank dan ATM untuk masuk ke halaman Lokasi Bank dan ATM.

3. Sistem menampilkan halaman Lokasi Bank dan ATM.

2. Sequence Diagram

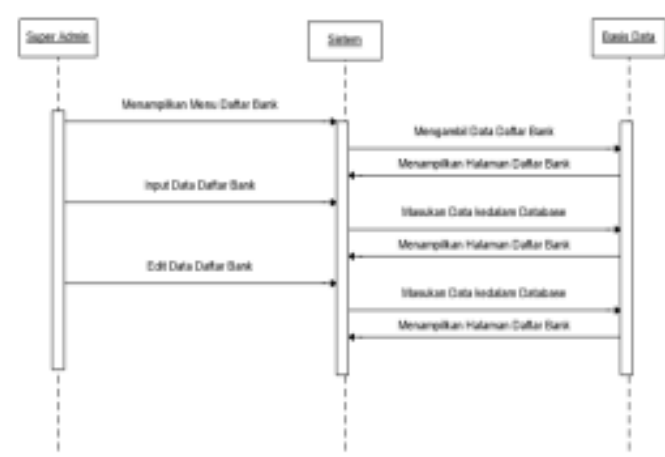

Gambar 9 Diagram Sequence "Daftar Bank"

Keterangan:

1. Pada saat super admin telah berada dalam halaman belakan maka super admin memilih menu daftar bank.

2. Setelah memilih menu daftar bank maka data daftar bank tersebut akan diambil dari database.

3. Kemudian akan tampil halaman input dan edit daftar bank dan admin sudah bisa menginput dan mengedit data bank.

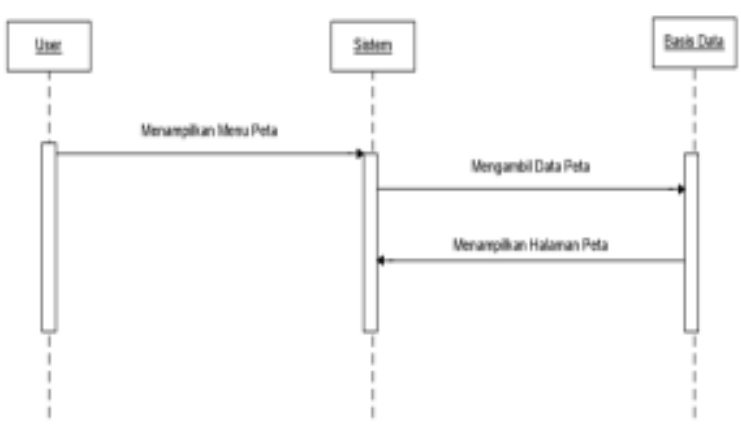

Gambar 10 Diagram Sequence "Lokasi Bank dan ATM"

Keterangan:

1. User akan memilih menu Lokasi Bank dan ATM apa bila user ingin melihat Lokasi Bank dan ATM.

2. Maka data Lokasi Bank dan ATM akan diambil dari database kemudian akan di tampilkan pada interface.

B. Impementasi Sistem

Dari perangcangan sistem diatas maka dapat diimplementasikan hasil perancangan "GIS Pencarian Lokasi Bank dan ATM Di Kota Ternate" terdapat tiga user di antaranya Super admin yang dapat mengakses semua halaman yang ada dan juga dapat menambahan data dan mengubah data yang ada pada sistem, Admin yang dapat mengolah sistem seperti super admin tetapi ada batasan untuk admin dalam mengolah data dalam sistem, sedangkan user hanya bisa melihat data yang ada pada sistem. Berikut ini tampilan di dalam sistem: 1. Menu Daftar Bank

Menu daftar bank merupakan informasi tentang bank apa saja yang ada di Kota Ternate dan alamat dari bank tersebut. 


\section{Sistem Informasi Geografis Pencarian Lokasi Bank Dan Atm Di Kota Ternate Berbasis Web}

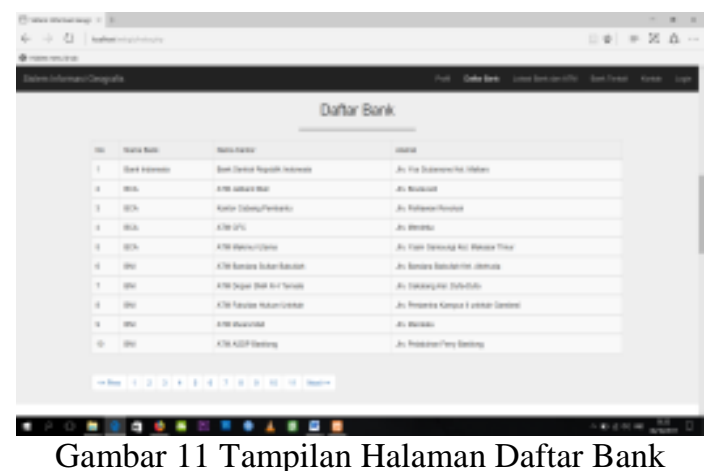

2. Menu Lokasi Bank dan ATM

Memberikan informasi tentang letak dari lokasi bank beserta informasi berupa nama bank, jumlah atm dan alamat dari tiap-tiap bank yang ada seperti pada gambar 4.31 dan gambar 4.32

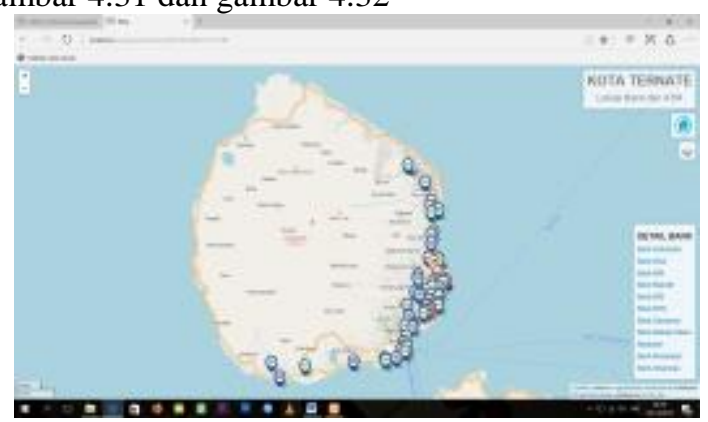

Gambar 12 Tampilan lokasi bank dan ATM

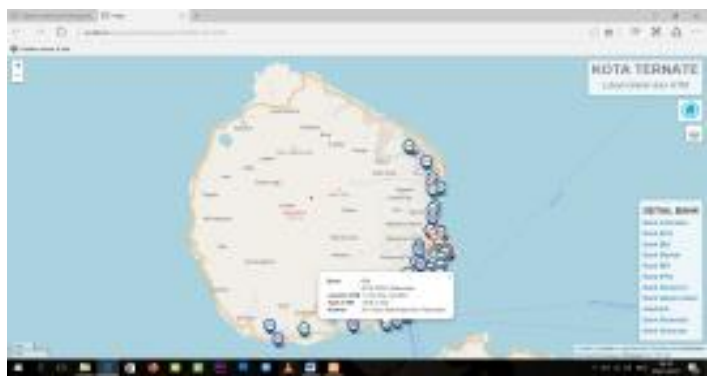

Gambar 13 Informasi Lokasi

\section{Pengujian Sistem}

Pada tahapan pengujian sistem ini, sistem akan diuji menggunakan pengujian blackbox, dimana pengujian blackbox tidak sampai ke algoritma sistem yang dibangun akan tetapi pengujian blackbox merupakan pengujian yang menguji fungsi-fungsi dari setiap menu pada sistem. Berikut ini hasil dari pengujian sistemnya.

1. Halaman Login

Tabel 1 Pengujian Halaman Login

\begin{tabular}{|c|c|c|}
\hline \multicolumn{3}{|c|}{ Pengujian Proses Login } \\
\hline \multicolumn{2}{|l|}{ Actor } & Administrator \\
\hline \multicolumn{2}{|l|}{ Menu } & Login \\
\hline \multicolumn{2}{|c|}{ Aktivitas Proses Rancangan } & $\begin{array}{l}\text { 1. Akses Halamen Login } \\
\text { 2. Masukan usemame dan password } \\
\text { 3. Kik tombol Login }\end{array}$ \\
\hline \multirow[t]{2}{*}{ Tanda } & $\begin{array}{l}\text { Peningalan } \\
\text { kesalahan }\end{array}$ & $\begin{array}{l}\text { Usemame dan password salah !!! } \\
\text { Login Kembal }\end{array}$ \\
\hline & Ksesuain Sistem & Depet melakikan login login Sukses" \\
\hline \multirow{2}{*}{ Hasil } & warning & $O_{k}$ \\
\hline & Acoepl & $O K$ \\
\hline \multicolumn{2}{|c|}{ Keterangan } & . \\
\hline
\end{tabular}

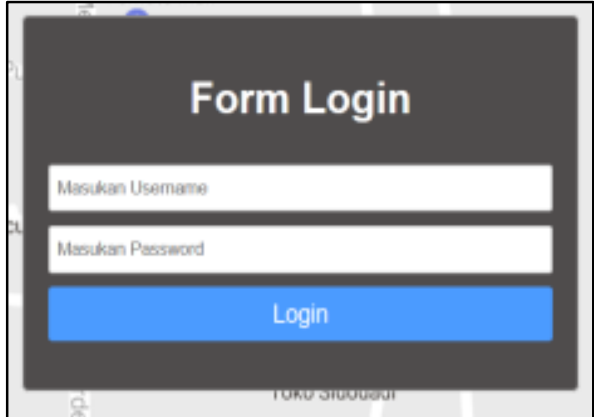

Gambar 14 Tampilan Login

Pada gambar yang digambarkan diatas merupakan gambaran halaman login yang dapat dialses oleh admin dan user.

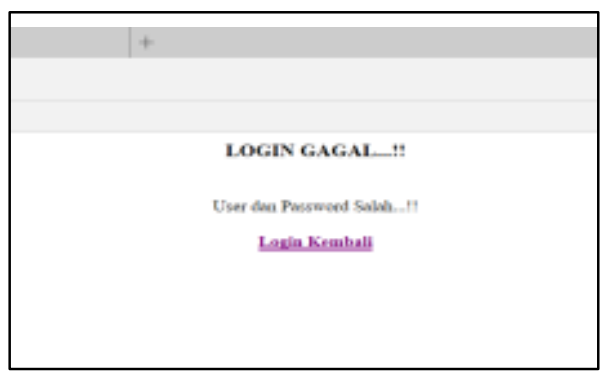

Gambar 15 Login Gagal

Pada gambar 15 merupakan hasil login gagal apabila super admin/admin memasukan username dan password salah, sehingga super admin / admin diminta untuk login kembali.

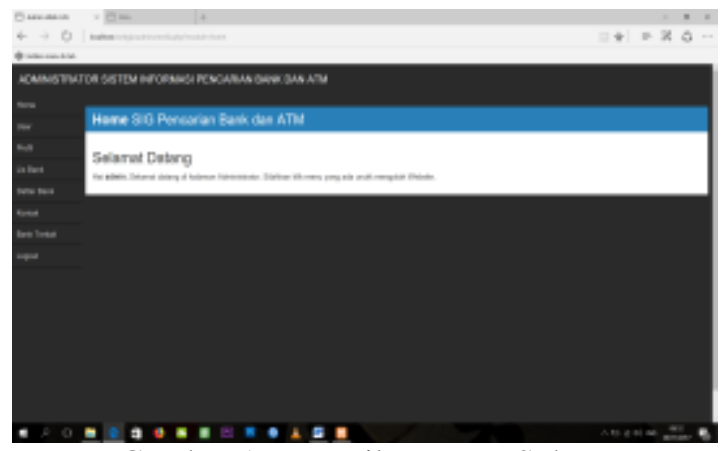

Gambar 16 Tampilan Login Sukses

Pada gambar 16 merupakan hasil login apabila super admin/admin memasukan username dan password benar.

2. Halaman Bank

Tabel 2 Pengujian Halaman Daftar Bank

\begin{tabular}{|c|c|c|}
\hline \multicolumn{3}{|c|}{ Penquian halaman Doftar Bank } \\
\hline \multicolumn{2}{|l|}{ Actor } & Administrator \\
\hline \multicolumn{2}{|l|}{ Menu } & Daftar Bank \\
\hline \multicolumn{2}{|c|}{ Akfivitas Proses Rancangan } & $\begin{array}{l}\text { 1. Püh menu Daftar Bank } \\
\text { 2. Püh tambah Bark } \\
\text { 3. Isi data sesuai dengan nama bark } \\
\text { 4. Klik fombol simpan }\end{array}$ \\
\hline \multirow[t]{2}{*}{ Tanda } & $\begin{array}{l}\text { Peringatan } \\
\text { kesalahan }\end{array}$ & - \\
\hline & Ksesuaian Sistem & - \\
\hline \multirow{2}{*}{ Hasil } & Warning & - \\
\hline & Accoept & Ok \\
\hline \multicolumn{2}{|c|}{ Keterangan } & - \\
\hline
\end{tabular}




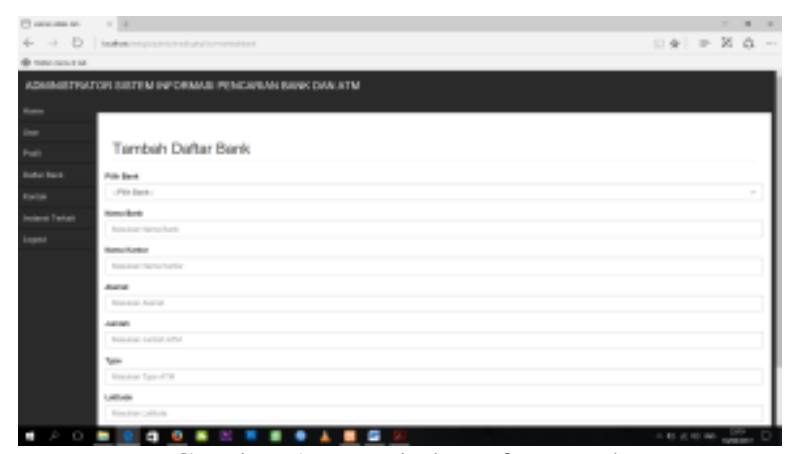

Gambar 17 Tambah Daftar Bank

3. Halaman Lokasi Bank dan ATM

Tabel 3 Pengujian Halaman Lokasi Bank dan ATM

\begin{tabular}{|c|c|c|}
\hline \multicolumn{3}{|c|}{ Penguian halaman Lokasi Bark dæn ATM } \\
\hline \multicolumn{2}{|l|}{ Aclor } & Adminstrdor \\
\hline \multicolumn{2}{|l|}{ Menu } & Lokasi Bark dan ATM \\
\hline \multicolumn{2}{|c|}{ Aktivitas Proses Rancangan } & $\begin{array}{l}\text { 1. Pilh menu Lokes Bank dan ATM } \\
\text { 2. Kik ioon bark pada Lokas Bark dan } \\
\text { ATM } \\
\text { 3. Tampil informasi bark }\end{array}$ \\
\hline \multirow[t]{2}{*}{ Tanda } & $\begin{array}{l}\text { Peringatan } \\
\text { kesslahan }\end{array}$ & - \\
\hline & \begin{tabular}{|l} 
Ksesusian Sisleam \\
\end{tabular} & - \\
\hline \multirow{2}{*}{ Hasl } & waming & - \\
\hline & Accopt & Ok \\
\hline \multicolumn{2}{|c|}{ Keterargan } & . \\
\hline
\end{tabular}

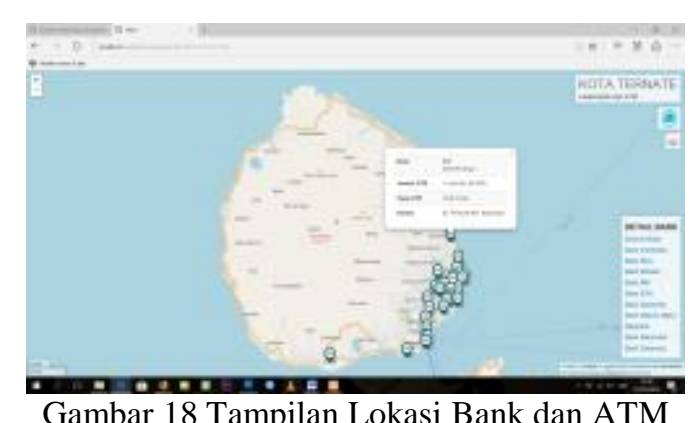

D. Analisis

Dari hasil perancangan Sistem Informasi Geografis Pencarian Lokasi Bank dan ATM di Kota Ternate Berbasis Web, sistem yang dibangun dari tahapan perancangan mengunakan use case diagram, activity diagram, sequence diagram dapat berjalan sesuai dengan fungsi menu yang ada pada sistem, terdapat dua tampilan dalam sistem yang dibangun yaitu halaman depan (front end) yang terdiri dari menu profil, daftar bank, lokasi bank dan ATM, bank terkait, kontak, login, dan halaman belakan (back end) yang terdiri dari menu home, user, profil, daftar bank, kontak, bank terkait, dan logout.

Pada implementasi sistem sudah berjalan sesuai dengan perancangan yang dibangun, dimana pada tiap-tiap menu sudah bisa diakses dan digunakan sesuai fungsi dari tiap-tiap menu tersebut. Menu yang diakses dapat berjalan dengan lancar seperti pada menu daftar bank dimana data yang diinput dapat tersimpan dalam sistem dan dapat diubah kembali sesuai dengan perancangaan yang diinginkan.
Untuk pengujian sistem telah sesuai dengan tahapan yang diuji dimana untuk pengujian sistem digunakan pengujian black box yaitu pengujian untuk melihat kecocokan data yang diakses, fungsi yang hilang atau tidak benar, dan error dari antarmuka yang terjadi didalam sistem. Seperti pengujian pada menu login apabila data username dan password yang dimasukan benar maka akan ditampilkan halam belakan (back and) apabila username dan password salah maka akan ditampilkan pesan bawah login gagal username dan password salah

\section{PENUTUP}

\section{A. Kesimpulan}

Berdasarkan penelitian yang dilakukan dan telah dibahas pada bab-bab sebelumnya, maka dapat diambil kesimpulan sebagai berikut :

1. Perancangan aplikasi sistem informasi geograafis pencarian lokasi bank dan atm di Kota Ternate dengan tahapan-tahapan mulai dari gambar rancangan yang digambarkan menggunakan use case diagram, activity diagram, sequence diagram, class diagram dan flowchart, dimana masing-masing diagram membahas secara keseluruhan dari sistem, bagaimana aktor mengoperasikan sistem yang di bangun, gambaran tentang aktivitas yang terjadi di dalam sistem, apa saja yang di lakukan oleh user dalam sistem, sampai dengan gambaran tabel-tabel apa saja yang ada di dalam database sistem, bagaimana tabel-tabel tersebut dapat berelasi dan gambaran tentang bagan alir pada sistem yang dibangun.

2. Aplikasi sistem informasi geografis yang dibangun mengukan bahasa pemograman PHP, Postgresql sebagai database dan menggunakan boostrap untuk membuat tampilan lebih fleksibel, sedangkan untuk pembuatan Lokasi Bank dan ATM digunakan QGIS (Quantum GIS) dan Leaflet js.

B. Saran

Hasil dari aplikasi Sistem Informasi Geografis Pencarian Lokasi Bank dan ATM masih terdapat kekurangan yang belum dipenuhi oleh perancang, diharapkan kedepan nanti dapat di kembangkan aplikasi tersebut sehingga aplikasi dapat di manfaatkan oleh pihak-pihak yang membutuhkan aplikasi tersebut, antara lain:

1. Pengkelompokan Bank Suasta dan Pemerintah

2. Membuat penentuan jarak dari lokasi user ke lokasi tujuan yang dekat

3. Membuat control point untuk masing-masing bank pada Lokasi Bank dan ATM.

4. Membuat searching pencarian untuk lebih memudahkan user dalam mencari lokasi bank dan ATM. 


\section{DAFTAR PUSTAKA}

[1] Az Putra. 2015. Pengertian ATM (Automatic Teller Machine)

[2] Bhaktiana. 2014. Kondisi Keagamaan di Ternate

[3] Owo Sugiana, 2001, SQL dengan Postgers

[4] Anisah Aini. 2008. Sistem Informasi Geografis Pengertian dan Aplikasinya. STIMIK AMIKOM. Yogyakarta

[5] Arif. 2012. Rancang Bangun Website Program Studi DIV Komputer Multimedia STIKOM Surabaya. Surabaya
[6] BPS. 2016. Kota ternate Dalam angka 2015. Badan Pusat Statistik Kota Ternate

[7] Eddy Prahasta. 2014. Sistem Informasi Geografis Konsep-Konsep dasar. Informatika, Bandung

[8] Fathansyah. 2012. Basis Data. Informatika, Bandung.

[9] Fadli Reza. 2014. Prototype Web Responsive Desain Pada Uin Syarif Hidayatullah Jakarta Menggunakan Framework Bootstrap, Jakarta.

[10] Hanif, Al, Fatta, 2007, Analisis Perancangan Sistem Informasi, Jogyakarta

[11] Jogiyanto. 2005. Analisis dan Desain Sistem Informasi. Yogyakarta 